\title{
THE INFLUENCE OF INTERGOVERNMENTAL REVENUE BUDGETS AND CLARITY OF BUDGET TARGETS ON THE FINANCIAL PERFORMANCE OF REGIONAL GOVERNMENTS: THE CASE OF THE REGIONAL APPARATUS ORGANIZATION OF THE CITY OF TIDORE ISLANDS
}

\author{
Farid Madjodjo ${ }^{1}$, Charis Muhammad Saleh $^{2}$, Fadli Dahlan ${ }^{3}$ \\ ${ }^{1}$ Accounting Study Program, Faculty of Economics, Nuku University, Jl. Sultan Mansur, Tidore, 97813, \\ Indonesia \\ ${ }^{2}$ Accounting Study Program, Faculty of Economics, Nuku University, J1. Sultan Mansur, Tidore, 97813, \\ Indonesia \\ ${ }^{3}$ Management Study Program, Faculty of Economics, Nuku University, Jl. Sultan Mansur, Tidore, 97813, \\ Indonesia \\ ${ }^{1}$ Corresponding e-mail: madj.farid@gmail.com
}

\begin{abstract}
This study aims to test the relationship of intergovernmental revenue and clarity of budget targets on the regional government financial performance. This study uses quantitative approach with primary data obtained from the results of distributing questionnaires and then measured by using a five-point Likert scale. The population of this study is the Regional Apparatus Organization which is official in the city of Tidore Islands, with the number of samples that have been determined as many as 45 samples. The sampling technique of this study is purposive sampling and conducts the multiple linear regression analysis as hypothesis testing. This study finds that the intergovernmental revenue and clarity of budget targets in partial have positive and significant effect on the regional government financial performance. The findings of this study imply that agency theory can explain the performance of local government of the City of Tidore Islands.
\end{abstract}

Keywords: intergovernmental revenue; clarity of budget targets; regional government financial performance

JEL Classification: H11, H77, H83

Article info:

Received 12 November 2020

Revised 25 November 2020

Accepted 25 November 2020

Available online 25 November 2020

\section{INTRODUCTION}

The implementation of regional autonomy as regulated in the Indonesian law number 32 in year of 2004 about the Regional Government and the Indonesian law number 33 in the year 2004 about the Financial Balancing between the Central Government and the Regional Governments are giving broad authority to local governments, both regencies and cities, to manage their own households in the fields of development, governance, and society, so the management of local governments is becoming increasingly important in people's lives. Most the people normally want to know how the regional or local governments manage their regions. The information that local governments disclose to the community must be clear. This information is in the form of financial and non-financial information which is used to assess the performance of local governments and is the responsibility of the local government to the community and third parties who provide financing. Disclosure of information could be done by local governments through the electronic media namely the official website (or called e-government). 
One of the performance measurements that can be called as the performance of local governments is the measurement of financial performance (Sari et al., 2016). The financial performance is one measure that can be used to ensure the ability of a region to properly and correctly implement financial implementation rules to maintain the desired services where higher assessment is a requirement that must be met in order for external parties to decide to invest in the region. The local government's financial performance is an important matter for local governments and external parties. Financial performance measurement data sourced from financial information which measured based on the budget that has been made, and it can be a further program improvement in order to produce better and better quality public services (Sari et al., 2016).

The sub-optimal financial performance of local governments has resulted in a decline in people's welfare. As one of the efforts and objectives in realizing good governance, namely by being accountable for the success or failure of the organization's mission in achieving the goals and objectives that have been set through an accountability medium which is carried out periodically (Wahid et al., 2016). The ability of regional governments to manage finances is outlined in the Regional Budget of Revenue and Expenditure (or called APBD) which directly or indirectly reflects the ability of the regional government to finance the implementation of governmental tasks, development, and community social services so that local governments are obliged to convey accountability for the use of the APBD to the public in the form of financial reports as a form of accountability to the community public.

The public's spotlight on the Regional Government of the City of Tidore Islands in terms of government performance, both financial and non-financial performance have not been maximized, the government as one of the parties authorized to manage the government in the City of Tidore Islands must be accountable for financial and non-financial performance which is easily accessible to the public at large so that people feel that there is transparency in the accountability of the government to the public and other parties who need this information. The performance of the Government of Tidore Islands City in terms of financial aspects is still not transparent to the people of Tidore Islands City. There is a budget that the regional government receives from other parties in the management of regional government finances, such as intergovernmental revenue. The budgets obtained by the Government of Tidore Islands City must have clear budget targets so that they can be used optimally to support the economy in the area of Tidore Islands City. The budgets obtained by the government must provide accountability in a transparent manner to the community so that the public can also assess the government's performance in terms of budget management.

Novyandra (2016) argues that intergovernmental revenue is measured by the balance fund to total revenue and shows that intergovernmental revenue affects the performance of district/city governments. Novyandra (2016) implies that the greater the level of dependence on the central government, the lower the performance of the region. Moreover, Suwandi (2013) indicates that the clarity of budget targets has a significant positive effect on local government performance which shows that the better the clarity of budget targets the better the government's performance will be produced by the government. The objective of this study is to answer the following questions: (1) does the intergovernmental revenue affect the financial performance of local governments?; and (2) does the clarity of budget targets affect the financial performance of local governments?

\section{LITERATURE REVIEWS}

\subsection{Agency theory}

There are two parties who make an agreement or contract in the context of agency relationship, namely the party that gives authority or the principal and the one who receives the authority or agent (Minarsih, 2015). In an organization, this relationship is vertical, 
namely between the superior as the principal and the subordinate as the agent (Marhawai, 2015). One of the theories that explain the principal and agent relationships is rooted in economic theory, decision theory, sociology and organizational theory (Minarsih, 2015). Furthermore, one party (principal) makes a contract, either implicitly or explicitly with the other party (agent) with the expectation that the agent will act/perform the job as desired by the principal (in this case a delegation of authority occurs).

In the process of budget formulation and amendment, two perspectives emerge indicating the application of agency theory, namely the relationship between the people and the legislature, and between the legislature and the executive. In the agency relationship between the legislature and the executive, the executive is the agent and the legislature is the principal (Minarsih, 2015). According to Masdiantini and Erawati (2016), the implementation of policies on the implementation of regional autonomy in Indonesia has brought about a very basic paradigm and structure change, especially for the functions of regional government (executive) with the function of people's representatives (legislative). According to Minarsih (2015) that in relations with the people, the legislature is an agent who defends the interests of the people (principals), however, there is no clear mechanism and regulation and control in delegating people's authority to the legislature. Furthermore, this is what often causes budget distortion prepared by the legislature so that the budget does not reflect the allocation of resource fulfillment to the community, but tends to prioritize the self-interest of the legislative parties.

\subsection{The basic concepts}

Regional government financial performance. According to Sumarjo (2010), the regional government financial performance is the output/outcome of activities/programs that will be or have been achieved in connection with the use of regional budgets with measurable quantity and quality, where regional capacity can be measured by assessing the efficiency of services provided to the community. Meanwhile, Adhiantoko (2013) states that the regional government financial performance is the ability of a region to explore and manage regional original financial sources in fulfilling its needs in order to support the running of the government system, services to the community, and regional development without being completely dependent on the central government and having the flexibility in using funds for the interests of the local community within the boundaries determined by statutory regulations. According to Bastian (2001:267), performance indicators are quantitative and qualitative measures that describe the level of achievement of predetermined goals and objectives by taking into account the elements of performance indicators input, output, outcome, benefit, and impact. Bastian (2001:267) states that the purpose of indicators of input, output, benefit, outcome and impact are: (1) input or everything that is needed for the implementation of the activities can be run to produce output; (2) output or something that is expected to be achieved directly from an activity which can be physical or non-physical; (3) outcome or anything that reflects the functioning of activity outputs in the medium term; (4) benefit or something related to the ultimate goal of implementing the activity; and (5) impact or an effect that is both positive and negative.

Intergovernmental revenue. The intergovernmental revenue is revenue received by local governments that comes from external sources and does not require repayment (Marhawai, 2015). Intergovernmental revenue is commonly known as the balance fund (Minarsih, 2015). According to Marhawai (2015), the balancing fund is the result of the central government's policy in the field of fiscal decentralization for the sake of fiscal balance between the central and regional governments, which consists of the Production Sharing Fund (taxes and natural resources), the General Allocation Fund (or called DAU), and the Special Allocation Fund (or called DAK). According to Jasmiati (2018), apart from being intended to assist the regions in funding their authority, the balancing fund also aims to 
reduce the imbalance of government funding sources between the central and regional governments and to reduce the gap in government funding between regions. According to Minarsih (2015), the financial balancing policy is emphasized on four main objectives, namely: (1) providing a source of funds for autonomous regions to carry out the assigned functions which are their responsibility; (2) reducing the fiscal gap between central and local governments and between local governments; (3) improve welfare and public services and reduce the disparity in welfare and public services between regions; and increasing the efficiency, effectiveness and accountability of the management of regional resources, particularly financial resources.

Clarity of budget targets. According to Efrizar (2017), the clarity of budget objectives is defined as a description of the breadth of the budget which is clearly and specifically stated and understood by the parties responsible for its achievement. Clarity of budget targets describes the extent of budget targets that are clearly stated and specifically understood by the party responsible for their achievement. According to Azmi et al. (2014), the clarity of budget targets must have the outcome to be achieved. Outcome is the benefit generated against the budget that has been implemented. Budget clarity must also see the priority scale. Priority activities must be prioritized so that budget targets are achieved. In the context of local government, budget targets are included in the Regional Strategic Plan (or called Renstrada) as well as programs and activities of Regional Apparatus Organizations (or called OPD). Program is the elaboration of the policy of the OPD in the form of efforts containing one or more activities using the resources provided to achieve measurable results in accordance with the mission of the OPD. According to Kanji (2016), there are seven important indicators for effective target measurement, namely: (1) purpose or makes in detail the general purpose of the tasks that must be done; (2) performance or establishes performance in the form of questions that are measured; (3) standard or sets the standard or target to be achieved; (4) timeframe or determines the time period needed for work; (5) priority targets or sets priority targets; (6) difficulty level or set targets based on the level of difficulty and importance; and (7) coordination or determines the need for coordination.

\subsection{Hypothesis development}

The relationship of intergovernmental revenue and regional government financial performance. Novyandra (2016) argues that intergovernmental revenue has a significant effect on the financial performance of district/city governments in Java Island. Aminah et al. (2019) show that intergovernmental revenue has a positive effect on local government administration. Sari et al. (2016) explains that the balancing fund has an effect on the financial performance of local governments while Minarsih (2015) finds that intergovernmental has no effect on the financial performance of local governments in Java partially for the efficiency ratio. Retnowati (2016) explains that intergovernmental has no effect on the financial performance of local governments. Masdiantini and Erawati (2016) argue that intergovernmental has no effect on the financial performance of district/city governments in Bali. Likewise, Jasmiati (2018) argues that intergovermental revenue has no effect on accountability of financial performance.

H1: the intergovernmental revenue is significant on the financial performance

The relationship of clarity of budget targets and regional government financial performance. Azmi et al. (2014) argue that the clarity of budget targets affects the performance of regional financial management. Susanto (2018) proves that the variable budget target clarity has a positive effect on the accountability of regional financial management. Yulianto (2019) shows that the clarity of budget targets has a positive and significant effect on the accountability of the performance of government agencies. Suwandi (2013) explains that the clarity of budget targets has a significant positive effect on the performance of the Padang City local government. Kaltsum and Rohman (2014) find that 
clarity of budget targets has a positive effect on the performance accountability of government agencies.

H2: the clarity of budget goals is significant on regional government financial performance

\section{RESEARCH METHOD}

\subsection{Sample}

This study conducts quantitative approach and uses survey method in the form of questionnaires in objective to determine the effect of intergovernmental revenue and the clarity of budget targets as independent variables on local government financial performance as the dependent variable. The location as the object of this study is the Regional Apparatus Organization of the Tidore Islands City in the Province of North Maluku. The population of this study are all employees of regional apparatus organizations in 15 agencies. The sample used in this study is the municipal government employees of Tidore Islands, with the criteria that have been determined are the head of the department, treasurer, and secretary which gives total for 45 people.

\subsection{Definition of variables}

The dependent variable of this study is regional government financial performance which defines as the output/outcome of activities/programs that will be or have been achieved in connection with the use of regional budgets with measurable quantity and quality, regional capacity can be measured by assessing the efficiency of services provided to the people (Sumarjo, 2010). The variable of regional government financial performance is measured by five-point Likert scale and given gradation from very positive to very negative, namely strongly agree with 5 point, agree with 4 point, disagree with 3 point, disagree with 2 point, and strongly disagree with 1 point.

The independent variables of this study are intergovernmental revenue and clarity of budget targets. The intergovernmental revenue is revenue received by local governments that comes from external sources and does not require repayment (Marhawai, 2015). The variable of intergovernmental revenue is measured by five-point Likert scale and given gradation from very positive to very negative, namely strongly agree with 5 point, agree with 4 point, disagree with 3 point, disagree with 2 point, and strongly disagree with 1 point. Furthermore, the clarity of budget targets is defined as a description of the extent of the budget which is clearly and specifically stated and understood by the parties responsible for its achievement (Efrizar, 2017). The variable of clarity of budget targets is also measured by five-point Likert scale and given gradation from very positive to very negative, namely strongly agree with 5 point, agree with 4 point, disagree with 3 point, disagree with 2 point, and strongly disagree with 1 point.

\subsection{Method of analysis}

This study conducts multiple linear regression analysis at significance level of 0.05 in term for hypothesis testing with model as follow.

$$
\mathrm{Y}=\alpha+\beta_{1} \cdot \mathrm{X}_{1}+\beta_{2} \cdot \mathrm{X}_{2}+\varepsilon
$$

Based on the model, $\mathrm{Y}$ is regional government financial performance, $\mathrm{X}_{1}$ is intergovermental revenue, $X_{2}$ is clarity of budget targets, $\alpha$ is constant, $\beta$ is regression coefficient, and $\varepsilon$ is standard error.

Multiple linear regression. According to Ayuningsih (2016), multiple regression analysis is a tool to predict the value of the effect of two or more independent variables on one dependent variable. This is to prove that there is a functional relationship or a causal relationship between two or more independent variables.

The $t$-test. The t test is done to test the hypothesis or the effect partially of each independent variable on the dependent variable (Suliyanto, 2011:55). This test can be done by comparing the significance level of each independent variable with $\alpha=0.05$. According to Ghozali 
(2011:100), the acceptance or rejection of the hypothesis is carried out with the criteria where if the $t_{\text {count }} \geq t_{\text {table }}$ or probability $\leq 0.05$ then the hypothesis is accepted which means that partially the independent variable has significant effect on the dependent variable. Reversely, if the $t_{\text {count }} \leq t_{\text {table }}$ or probability $\geq 0.05$ then the hypothesis is rejected which means that partially the independent variable does not have significant effect on the dependent variable.

The F-test. The F-test basically shows whether all the independent variables in the model have a joint effect on the dependent variable. In addition, the $F$ test can be used to see whether the regression model used is fit or not in case if $p$ value $\leq(\alpha)=0.05$ and $F_{\text {count }} \geq F_{\text {table }}$ then it means that the model is significant and can be used to test the hypothesis.

In supporting the regression model, this study conducts several testing such as validity test, reliability test, and classic assumption test.

The test of validity. According to Ghozali (2016:52), the validity test is used to measure whether a questionnaire is valid or not. To determine the validity of the questionnaire used, this study uses correlation between the score of the question items and the total variable score where if $r_{\text {count }} \geq r_{\text {table }}$ and it is positive then the indicator is valid whereas if the correlation value is below 0.05 then it can be concluded that the questions in the questionnaire are invalid (Ghozali, 2016:53).

The test of reliability. The reliability test is a tool used to measure a questionnaire which is an indicator of a variable. A questionnaire is said to be reliable or reliable if someone's question on the statements in the questionnaire is stable over time (Ghozali, 2016:47). A variable is said to be reliable if it has a Cronbach's Alpha $(\alpha)$ value $\geq 0.70$.

Classic assumption test. The classic assumption test for this study consists of normality test, multicollinearity test, and heteroscedasticity test.

1. Normality test. According to Sugiyono (2009:172), the use of parametric statistics requires that the residual must be normally distributed. The normality test for this study is the Kolmogorov-Smirnov test. According to Ghozali (2011:161), the basis for the decision making of the Kolmogorov-Smirnov test is if the asymp. sig. (2-tailed) value less than 0.05 then $\mathrm{H}_{0}$ is rejected which means that the residual is not normally distributed but if the asymp. sig. (2-tailed) value more than 0.05 then $\mathrm{H}_{0}$ is accepted which means that the residual is normally distributed.

2. Multicollinearity test. The multicolinearity test aims to test whether the regression model found correlation between independent variables. A good regression model should not have a correlation between the independent variables. If the independent correlates with each other, then this variable is not orthogonal or an independent variable whose correlation value between independent variables is equal to zero (Ghozali, 2011:105). The tolerance value and Variance Inflation Factor (VIF) are effective to detect the problem of multicollinearity. If the tolerance value $\leq 0.1$ and VIF $\geq 10$ then it means that multicollinearity problem occur between independent variables but if the tolerance value $\geq 0.1$ and VIF $\leq 10$ then it means that there is no multicollinearity between independent variables (Ghozali, 2011:106).

3. Heteroscedasticity test. The purpose of the heteroscedasticity test is to test whether in the regression model exists an inequality of variance from the residuals of one observation to another. If the residual variance from one observation to another is constant then it is called homoscedasticity and if it is different it is called heterocedasticity. This study conducts the Glejser test to test the heteroscedasticity by regresses the absolute residual value with the independent variables. According to Ghozali (2011:142), if the p-value is $\leq 0.05$ then the model has heteroscedasticity, however, if the p-value is $\geq 0.05$ then there is no heteroscedasticity. 
Descriptive statistics. Descriptive analysis is used to describe the data for each variables, namely, intergovernmental revenue and clarity of budget targets as independent variables, and local government financial performance as the dependent variable.

The correlation coefficient $(R)$ and coefficient of determination $\left(R^{2}\right)$. The correlation is used to measure the strength of linear association between two variables. The coefficient determination is a value that indicates how much the independent variables can explain the dependent variable. In this study, using the adjusted $R^{2}$ ranges between 0 and 1 . The value of adjusted $\mathrm{R}^{2}$ is getting closer to 1 then better ability of the model to explain the dependent variable. Conversely, if the adjusted $\mathrm{R}^{2}$ far from 1 then ability of the model to explain the dependent variable is less predictive (Ghozali, 2011:190).

\section{RESULTS AND DISCUSSIONS}

\subsection{Results}

Descriptive statistics. Table 1 presents that the sample $(\mathrm{N})$ of this study are 45 respondents. The lowest value of the data is indicated by the minimum score while the highest value of the data is indicated by the maximum score. The mean is used to measure the average value of the data and the standard deviation shows the standard savings. The intergovernmental revenue (X1) has a minimum score of 9 and a maximum score of 15, so that an average score of 11.31 is obtained and a standard deviation of 1.781 . The clarity of budget targets (X2) has a minimum score of 23 , a maximum score of 37 , so that an average score of 30.93 is obtained, and a standard deviation of 3,460. The regional government financial performance variable (Y) has a minimum score of 24 , a maximum score of 34 , so that an average score of 29.91 is obtained, and a standard deviation of 2.466.

Table 1. Descriptive statistics

\begin{tabular}{cccccc}
\hline Variables & N & Minimum & Maximum & Mean & Std. Deviation \\
\hline X1 & 45 & 9 & 15 & 11.31 & 1.781 \\
X2 & 45 & 23 & 37 & 30.93 & 3.460 \\
Y & 45 & 24 & 34 & 29.91 & 2.466 \\
Valid N (listwise) & 45 & & & & \\
\hline
\end{tabular}

Validity and reliability tests. Table 2 shows that that intergovernmental revenue (X1) has 3 statement items and each statement items show the value $r_{\text {count }} \geq r_{\text {table. }}$. The clarity of budget targets (X2) has 8 statement items and each statement items show the value of $r_{\text {count }} \geq$ $\mathrm{r}_{\text {table. }}$ The local government financial performance variable $(\mathrm{Y})$ has 7 statement items and each items show the value of $r_{\text {count }} \geq r_{\text {table. }}$. Those results means that all statement items of all variables are valid. Table 2 also shows that each variables have value of Cronbach's Alpha value more than 0.7 which means all instruments of this study are reliable.

Table 2. Validity and reliability tests

\begin{tabular}{cccc}
\hline & \multicolumn{1}{c}{$\mathbf{R}_{\text {count }}$} & \\
\cline { 2 - 4 } Statement & $\begin{array}{c}\text { Intergovernmental } \\
\text { revenue } \\
(\mathbf{X 1})\end{array}$ & $\begin{array}{c}\text { Clarity of budget } \\
\text { targets } \\
(\mathbf{X 2})\end{array}$ & $\begin{array}{c}\text { Regional government } \\
\text { financial performance } \\
(\mathbf{Y})\end{array}$ \\
\hline 1 & 0.924 & 0.838 & 0.846 \\
2 & 0.949 & 0.699 & 0.776 \\
3 & 0.893 & 0.785 & 0.616 \\
4 & & 0.822 & 0.420 \\
5 & & 0.778 & 0.545 \\
6 & & 0.682 & 0.711 \\
7 & & 0.701 & \\
\hline 8 & 0.287 & 0.594 & 0.287 \\
\hline $\mathrm{R}_{\text {table }}$ & 0.903 & 0.287 & 0.769 \\
\hline
\end{tabular}


Classic assumption test. Table 3 presents the normality test and shows that the residual error of regression model is normally distributed as reflected by KolmogorovSmirnov value of 0.844 with Asymp.Sig $0.561 \geq \alpha=0.05$.

Table 3. Normality test (One-Sample Kolmogorov-Smirnov Test)

\begin{tabular}{lrr}
\hline & & Unstandardized Residual \\
\hline N & & 45 \\
Normal Parameters & Mean & $0 \mathrm{E}-7$ \\
& Std. Deviation & 1.54861129 \\
Most Extreme Differences & Absolute & 0.126 \\
& Positive & 0.126 \\
& Negative & -0.084 \\
Kolmogorov-Smirnov Z & & 0.844 \\
Asymp. Sig. (2-tailed) & & 0.561 \\
\hline
\end{tabular}

Table 4 presents multicollinearity test which shows that the Variance Inflation Factor (VIF) for each independent variables are less than 10 and tolerance are above 0.1. Those results indicate there is no multicollinearity problem among the independent variables in the regression model that is formed.

Table 4. Multicollinearity test

\begin{tabular}{lccc}
\hline \multirow{2}{*}{ Variables } & \multicolumn{2}{c}{ Collinearity Statistics } \\
\cline { 2 - 3 } & Tolerance & VIF \\
\hline X1 & 0.875 & 1.143 \\
X2 & 0.875 & 1.143 \\
\hline
\end{tabular}

Table 5 presents the heteroscedasticity test which shows that all independent variables are insignificant (greater than $\alpha=0.05$ ) on absolute residual error of regression model which means that there is no heteroscedasticity in regression model of this study.

Table 5. Heteroscedasticity test

\begin{tabular}{lccccc}
\hline \multirow{2}{*}{ Model } & \multicolumn{1}{c}{ Unstandardized Coefficients } & Standardized Coefficients & \multirow{2}{*}{ T } & \multirow{2}{*}{ Sig. } \\
\cline { 2 - 4 } & B & Std. Error & Beta & & 1.855 \\
Constant & 1.971 & 1.063 & 0.087 & 0.071 \\
X1 & 0.035 & 0.066 & -0.157 & 0.534 & 0.596 \\
X2 & -0.033 & 0.034 & -0.964 & 0.341 \\
\hline
\end{tabular}

Dependent Variable is absolute residual (Abs_RES) follow.

Multiple linear regression. Table 6 presents the results of multiple linear regression as

1. The intergovernmental revenue and local government financial performance. The result of t-test shows that the intergovermental revenue variable $(\mathrm{X} 1)$ has significant value of $t$ is $0.003 \leq$ significance level of alpha $=0.05$ and the value of $t_{\text {count }} \geq t_{\text {table }}$ is $3.157 \geq$ 1.679 which means first hypothesis (H1) is accepted.

2. The clarity of budget targets and local government financial performance. The result of t-test shows that the clarity of budget targets has a significant value of $t$ of $0.000 \leq$ significance level of alpha $=0.05$ and the value of $t_{\text {count }} \geq t_{\text {table, }}$, namely $5.793 \geq 1.679$ which means the second hypothesis ( $\mathrm{H} 2)$ is accepted.

Table 6 also shows that the value of $R$ is 0.778 which indicates that there is strong relationship between independent variables and dependent vaiable. Moreover, Adjusted $\mathrm{R}$ Square is 0.587 which indicates that the contribution of the intergovernmental revenue variable (X1) and the clarity of budget targets (X2) is 0.587 or $58.7 \%$ while $41.3 \%$ is influenced by other factors that are not examined. The result of F-test shows that the significant value $\rho$ value $\leq \alpha$ (alpha) is $0.000 \leq 0.05$, and $F_{\text {count }} \geq F_{\text {table, }}$, namely $32.265 \geq 3.204$ which means that the model used in this study is fit. 


\begin{tabular}{|c|c|c|c|c|c|}
\hline \multicolumn{6}{|c|}{ Table 6. Multiple linear regression test } \\
\hline \multirow{2}{*}{ Model } & \multicolumn{2}{|c|}{ Unstandardized Coefficients } & \multirow{2}{*}{$\begin{array}{c}\text { Standardized Coefficients } \\
\text { Beta } \\
\end{array}$} & \multirow{2}{*}{$\mathbf{T}$} & \multirow{2}{*}{ Sig. } \\
\hline & B & Std. Error & & & \\
\hline Constant & 11.561 & 2.298 & & 5.030 & 0.000 \\
\hline $\mathrm{X} 1$ & 0.453 & 0.143 & 0.327 & 3.157 & 0.003 \\
\hline $\mathrm{X} 2$ & 0.428 & 0.074 & 0.600 & 5.793 & 0.000 \\
\hline \multicolumn{6}{|c|}{ Dependent Variable: Y } \\
\hline $\mathrm{R}$ & & & & & \\
\hline R Square & & & & & \\
\hline Adjusted R & & & & & \\
\hline Std. Error o & & & & & \\
\hline F-test (signi & 05) & & & & \\
\hline
\end{tabular}

\subsection{Discussions}

The relationship of intergovernmental revenue and regional government financial performance. This study finds that intergovernmental revenue partially has a positive and significant effect on the financial performance of the local government of Tidore Islands City. This shows that intergovernmental revenue is an important factor in measuring the financial performance of the local government of Tidore Islands City. Thus, intergovernmental revenue is very important to improve financial governance that can improve the financial performance of the local government of Tidore Islands City. The lower the intergovernmental revenue received then it shows that the dependence of the Tidore Islands City regional government on other local governments as well as from the central government is very low as well. If the low dependence of the local government of Tidore Islands City on intergovernmental revenue, it can be illustrated that the level of independence of the Tidore Islands City regional government in managing local revenue sources is very good. The results of this study support for Novyandra (2016) for the study at the municipal and district governments in Java Island in year 2014, Aminah et al. (2019) for a case study in the West Java region, and Sari et al. (2016) for study on an Island Regency/City Sumatera. Reversely, the results of this study are inconsistent with Minarsih (2015) for case study of local governments in Central Java, Retnowati (2016) for the case of Regional/City Governments in Central Java 2011-2013, Masdiantini and Erawati (2016) for case study in Regency/City governments in Bali, and Jasmiati (2018) for empirical study on Enrekang Regency Government.

The relationship of Clarity of Budget targets and Regional Government Financial Performance. This study find that the clarity of budget targets has a positive and significant effect on the financial performance of the Tidore Islands City government. This illustrates that the clarity of budget targets is an important thing in measuring the financial performance of the local government of Tidore Islands City. The results of this study prove that the clarity of budget targets is an indicator of financial performance that can show the accountability of the local government of Tidore Islands City in a transparent manner. The better the clarity of budget targets then better the financial performance of local governments will be. The results of this study are consistent with the study of Azmi et al. (2014) in the Aceh government environment, Susanto (2018) in study of SKPD East Luwu Regency, Yulianto (2019) for case in Pati district government, Suwandi (2013) for study on SKPD Padang City Government, and Kaltsum and Rohman (2014) for study on the Salatiga City Regional Work Units.

\section{CONCLUSION}

This study concludes that intergovernmental revenue plays important role to increase the financial performance of the local governments in context of agency theory although higher the Regional Expenditure Budget will show that the financial performance of the regional government has not been too maximal in the management of revenue sources in their own regions, so that the regions are still very dependent on central funding assistance, namely 
intergovernmental revenue. This study also concludes that clarity of budget targets is a significant factor to increase the financial performance of the local governments in context of agency theory which indicates that the financial performance of local governments is in dire need of precise targets for the use of regional budgets for the benefit of public welfare. In addition, every report on the financial performance of the regional government must have clarity on the budget used in accordance with the use of work programs that are prioritized for the welfare of the community, so that the community feels the satisfaction of services provided by the regional government as a duty to manage the area properly according to community needs.

Based on those results, this study suggests that the Regional Government of the City of Tidore Islands as the party making policies in controlling and managing the regions related to budget management to increase the monitoring on every government work program which gives the right target area in objective for the welfare of society. Moreover, each report on the government's financial performance also prioritizes clarity of budget targets so that government performance will be further improved, thus the government can maximize its performance to explore sources of regional revenue in managing its own regions without depending on budget assistance from the center. This study also suggests that for further researchers who are interested in developing research with the same title to use other data analysis methods, such as ratio analysis or using variance analysis on local government financial performance.

\section{REFERENCES}

Azmi, G., Darwanis, Abdullah, S. (2014). Pengaruh kejelasan sasaran anggaran, kualitas sumberdaya manusia dan komitmen organisasi terhadap kinerja pengelolaan keuangan daerah di Lingkungan Pemerintah Aceh. Jurnal Administrasi Akuntansi: Program $\begin{array}{lll}\text { Pascasarjana Unsyiah, } & \text { 3(4), }\end{array}$ http://www.jurnal.unsyiah.ac.id/JAA/article/view/4441

Ayuningsih, D. (2016). Pengaruh size, wealth, leverage, belanja daerah dan intergovernemental revenue terhadap kinerja keuangan Pemerintah Daerah di Jawa Tengah. Skripsi. Fakultas Ekonomi dan Bisnis Institut Agama Islam Negeri Surakarta. https://core.ac.uk/download/pdf/296469823.pdf

Adhiantoko, H. (2013). Analisis kinerja keuangan Pemerintah Kabupaten Blora (Studi kasus pada Dinas Pendapatan Pengelolaan Keuangan dan Aset Daerah Kabupaten Blora). Skripsi. Fakultas Ekonomi Universitas Negeri Yogyakarta. http://eprints.uny.ac.id/id/eprint/17846

Aminah, N. I., Afiah, N. N, \& Pratama, A. (2019). Pengaruh size, wealth, intergovermental revenue dan belanja modal terhadap kinerja pemerintah daerah. Jurnal Sistem Informasi, Keuangan, Auditing dan Perpajakan, 3(2), 147-165. http://183.91.79.105/index.php/sikap/article/view/137/pdf

Bastian, I. (2001). Akuntansi sektor publik di Indonesia, Edisi Pertama. Yogyakarta: BPFE.

Efrizar, R. (2017). Pengaruh kejelasan sasaran anggaran, akuntabilitas publik, dan sistem pelaporan terhadap kinerja manajerial (Studi empiris pada SKPD Kabupaten Rokan Hulu). JOM Fekon, 4(1), 1726-1740. https://media.neliti.com/media/publications/119209-ID-pengaruh-kejelasan-sasarananggaran-akun.pdf

Ghozali, I. (2011). Aplikasi analisis multivariate dengan program SPSS. Semarang: Badan Penerbit Universitas Diponegoro. 
Ghozali, I. (2016). Aplikasi analisis multivariate dengan program IBM SPSS 23, Edisi 8, Cetakan ke VIII. Semarang: Badan Penerbit Universitas Diponegoro.

Jasmiati. (2018). Intergovernmental revenue, ketepatan sasaran anggaran, dan sistem pelaporan terhadap akuntabilitas kinerja keuangan dengan sistem pengendalian intern sebagai variabel moderasi (Studi empiris pada Pemerintahan Kabupaten Enrekang). Skripsi. Repository UIN Alaudin Makassar. http://repositori.uin-alauddin.ac.id/12723/

Kanji, L. (2016). Pengaruh kejelasan sasaran anggaran, kinerja manajerial dan pelaporan/pertanggungjawaban anggaran terhadap akuntabilitas kinerja Instansi Pemerintah Daerah Kabupaten Enrekang. Jurnal Ilmiah Bongaya (Manajemen \& Akuntansi, XIX, 73-92. https://ojs.stiem-bongaya.ac.id/index.php/JIB/article/view/9

Kaltsum, U., \& Rohman, A. (2014). Pengaruh kejelasan sasaran anggaran terhadap akuntabilitas kinerja instansi pemerintah melalui sistem pengendalian intern sebagai variabel intervening (Studi empiris pada Satuan Kerja Perangkat Daerah Kota Salatiga). Diponegoro Journal of Accounting, 3(1) 1-14. https://ejournal3.undip.ac.id/index.php/accounting/article/view/6032/5820

Marhawai. (2015). Pengaruh ukuran legislatif, kemakmuran pemerintah daerah, ukuran pemerintah daerah dan intergovernmental revenue terhadap kinerja keuangan pemerintah daerah (Studi pada Kabupaten/Kota di Aceh tahun 2010 s.d 2014). Jurnal Telaah Riset Akuntansi, 8(1), 49-58. http://www.jurnal.unsyiah.ac.id/TRA/article/view/14684

Minarsih, R. A. (2015). Pengaruh size, wealth, leverage dan intergovernmental revenue terhadap kinerja keuangan pemerintah daerah di Jawa Tengah. Skripsi. Repository Universitas Negeri Semarang. https://lib.unnes.ac.id/22311/

Masdiantini, R. P., \& Erawati, A. M. N. (2016). Pengaruh ukuran pemerintah daerah, kemakmuran, intergovernmental revenue, temuan dan opini audit BPK pada kinerja Keuangan. E-Jurnal Akuntansi Universitas Udayana, 14(2), 1150-1182. https://ojs.unud.ac.id/index.php/Akuntansi/article/view/15041/12607

Novyandra, R. (2016). Pengaruh belanja modal, intergovernmental revenue, leverage, size, dan pendapatan asli daerah terhadap kinerja keuangan Pemerintah Daerah Kota dan Kabupaten di Pulau Jawa tahun 2014. Skripsi. Repository Universitas Muhammadiyah Surakarta. http://eprints.ums.ac.id/43410/

Retnowati, R. (2016). Analisis pengaruh tingkat kekayaan daerah, belanja daerah, ukuran pemerintah daerah, leverage dan intergovernmental revenue terhadap kinerja keuangan pemerintah daerah (Studi empiris pada Pemerintah Daerah/Kota Se-Jawa Tengah 2011-2013). Skripsi. Repository Universitas Muhammadiyah Surakarta. http://eprints.ums.ac.id/41380/

Sugiyono. (2009). Metode penelitian pendidikan pendekatan kuantitatif, kualitatif, dan R\&D. Bandung: Alfabeta.

Suliyanto. (2011). Ekonometrika terapan: Teori dan aplikasi dengan SPSS. Yogyakarta: ANDI.

Sumarjo, H. (2010). Pengaruh karakteristik pemerintah daerah terhadap kinerja keuangan pemerintah daerah. Skripsi. Repository Universitas Sebelas Maret. https://eprints.uns.ac.id/4060/

Suwandi, A. P. (2013). Pengaruh kejelasan sasaran anggaran dan desentralisasi terhadap kinerja pemerintah daerah (Studi empiris pada SKPD Pemerintah Kota Padang). Jurnal Akuntansi, $\quad 1(2), \quad 1-18$. http://ejournal.unp.ac.id/students/index.php/akt/article/view/608

Sari, I. P., Agusti, R., \& Rofika. (2016). Pengaruh ukuran pemerintah daerah, PAD, leverage, dana perimbangan dan ukuran legislatif terhadap kinerja keuangan pemerintah daerah (Studi pada Kab/Kota Pulau Sumatra). Jurnal Online Mahasiswa Fakultas Ekonomi 
Universitas

Riau,

$3(1)$,

679-692.

https://www.neliti.com/publications/115984/pengaruh-ukuran-pemerintah-daerahpad-leverage-dana-perimbangan-dan-ukuran-legis

Susanto. (2018). Pengaruh kejelasan sasaran anggaran dan penyajian laporan keuangan daerah terhadap akuntabilitas pengelolaan keuangan daerah (Studi di SKPD Kabupaten Luwu Timur). Skripsi. Universitas Hasanuddin Makassar. https://docplayer.info/78986008-Pengaruh-kejelasan-sasaran-anggaran-dan-penyajianlaporan-keuangan-daerah-terhadap-akuntabilitas-pengelolaan-keuangan-daerah.html

Yulianto, R. A. (2019). Pengaruh kejelasan sasaran anggaran, pengendalian akuntansi dan sistem pelaporan terhadap akuntabilitas kinerja Pemerintah Kabupaten Pati. Tirtayasa EKONOMIKA, 14(2), 204-219. http://dx.doi.org/10.35448/jte.v14i2.6478

Wahid, I., Nasir, A., \& Supriono. (2016). Pengaruh kejelasan sasaran anggaran, pengendalian akuntansi, kompetensi aparatur pemerintah daerah, sistem pelaporan, dan ketaatan pada peraturan perundangan terhadap akuntabilitas kinerja instansi pemerintah (Studi Empiris pada Satuan Kerja Perangkat Daerah Kabupaten Agam). Jurnal Online Mahasiswa Fakultas Ekonomi Universitas Riau, 3(1), 2457-2471. https://www.neliti.com/publications/122276/pengaruh-kejelasan-sasaran-anggaranpengendalian-akuntansi-kompetensi-aparatur-p

Undang-Undang No. 32 tahun 2004 tentang Pemerintahan Daerah

Undang-Undang No. 33 tahun 2004 tentang Perimbangan Keuangan antara Pemerintah Pusat dan Daerah 